\title{
CYP3A4*17 Allele
}

National Cancer Institute

\section{Source}

National Cancer Institute. CYP3A4*17 Allele. NCI Thesaurus. Code C46026.

Human CYP3A4*17 allele is located in the vicinity of 7q21.1 and is approximately $27 \mathrm{~kb}$ in length. This allele, a variant form of the CYP3A4 wild-type allele, encodes cytochrome P450 3A4*17 protein. The CYP3A4*17 allele exhibits a clinically-relevant SNP (g.15615T >C) in exon 7 that results in a F189S coding change. This alteration in protein sequence severely decreases the enzymatic activity of the cytochrome P450 3A4*17 protein. 